Falah: Jurnal Ekonomi Syariah

(p)ISSN: 2502-3918; (e)ISSN: 2502-7825

Vol 4, No 2 (Agustus 2019), pp.159-171

DOI: https://doi.org/10.22219/jes.v4i2.9873

\title{
Analisis Pendapatan Non Halal Perbankan Syariah Di Indonesia: Sumber Dan Penggunaannya
}

\author{
Rudy Hartanto, Irena Paramita Pramono \& Pupung Purnamasari \\ Program Studi Akuntansi, Fakultas Ekonomi dan Bisnis, \\ Universitas Islam Bandung \\ Email: rudyhartanto05@gmail.com
}

\begin{abstract}
The existence of the regulation for Islamic banking causes it to conduct their activities by the guidance of Islamic principles which avoid some non-halal sources of income. On the other hand, the transactions between Islamic banking and conventional banking are unavoidable because conventional financial institutions still dominate all transactions in each country. Means that non-halal sources of income cannot be avoided, by the way of transaction is done. This research aim to analyze on the sources of income and its distribution of the non-halal funds of Islamic Banks in Indonesia. This research is quantitative. The method of collecting data documentation uses data from 2015-2017 with a total sample of 102 Islamic banks. The results shows that there were differences in the average non-halal funds of Islamic Commercial Banks with Islamic Business Unit Bank. In addition, this study shows that Islamic commercial bank tend to have non-halal funds bigger than Islamic Business Unit Bank. On the other hand, the result shows that non-halal funds sources in the banking industry are dominated by interest income from another conventional bank and the using of nonhalal funds is dominated by social activities.
\end{abstract}

Keywords: Non-halal income, Islamic Bank, Islamic Principle, Economic Activities. 


\begin{abstract}
ABSTRAK
Peraturan perbankan syariah mengharuskan bahwa kegiatan yang dijalankan oleh bank syariah harus selaras dengan prinsip-prinsip Islam, diantaranya adalah menghindari beberapa sumber pendapatan non-halal. Di sisi lain, transaksi antara perbankan syariah dan perbankan konvensional tidak dapat dihindari karena lembaga keuangan konvensional masih mendominasi semua transaksi di masing-masing negara. Berarti sumber penghasilan non-halal tidak bisa dihindari. Penelitian ini bertujuan untuk menganalisis sumber pendapatan dan distribusinya terhadap dana non-halal Bank Syariah di Indonesia. Penelitian ini adalah kuantitatif. Metode pengumpulan data dokumentasi menggunakan data dari 2015-2017 dengan total sampel 102 bank syariah. Hasil penelitian menunjukkan bahwa terdapat perbedaan rata-rata dana non halal Bank Umum Syariah dengan Bank Unit Usaha Syariah. Selain itu, penelitian ini menunjukkan bahwa bank umum syariah cenderung memiliki dana non-halal lebih besar dari Bank Unit Bisnis Syariah. Di sisi lain, hasilnya menunjukkan bahwa sumber dana non-halal di industri perbankan didominasi oleh pendapatan bunga dari bank konvensional lain dan penggunaan dana non-halal didominasi oleh kegiatan sosial.
\end{abstract}

Kata Kunci: Penghasilan non-halal, Bank Islam, Prinsip Islam, Kegiatan Ekonomi.

\title{
1. Pendahuluan
}

Indonesia sebagai negara muslim terbesar di dunia turut berperan dalam perkembangan industri keuangan syariah di tingkat global. Hal tersebut dalam terlihat dari masuknya Indonesia sebagai salah satu dari 10 besar negara yang memiliki aset industri keuangan syariah terbesar di tingkat dunia (Thomson Reuters, 2016). Industri keuangan syariah Indonesia di klasifikasikan dalam beberapa jenis, dimana perbankan syariah memiliki peningkatan aset yang paling signifikan dibandingkan dengan industri keuangan syariah lainnya.

Tabel 1.1

Perkembangan Aset Industri Keuangan Syariah di Indonesia

\begin{tabular}{lclllll}
\hline Jenis Industri & 2013 & 2014 & 2015 & 2016 & 2017 & 2018 \\
\hline $\begin{array}{l}\text { Perbankan } \\
\text { Syariah }\end{array}$ & 248.11 & 278.92 & 304 & 365.03 & 435.02 & 444.43 \\
$\begin{array}{l}\text { Perusahaan } \\
\text { Asuransi }\end{array}$ & 16.66 & 22.36 & 26.52 & 33.24 & 40.52 & 41.85 \\
& & & & &
\end{tabular}

Vol. 4, No.2, Agustus 2019 
Syariah

Lembaga

Pembiayaan

24.64

31.67

22.35

35.74

34.48

29.51

Syariah

Lembaga Non-

Bank Syariah

8.25

12.25

$16.03 \quad 19.69$

24.14

26.98

Lainnya

Sumber: Statistik Perbankan Indonesia, 2018

Di Indonesia, peraturan mengenai perbankan syariah terdapat dalam UU No. 21 Tahun 2008 Tentang Perbankan Syariah. Peraturan tersebut mengatur agar perbankan syariah dalam melakukan kegiatan usahanya harus berasaskan prinsip syariah, demokrasi ekonomi dan prinsip kehati-hatian. Kepatuhan perbankan Syariah merupakan isu yang penting bagi stakeholders di Indonesia dikarenakan perbankan di Indonesia saat ini masih dinilai kurang sesuai dengan prinsip-prinsip Syariah (Suprayogi, 2013).

Selain sisi positif bank syariah, yang berkembang sangat massif (Ghozali, Azmi \& Nugroho, 2019). Terdapat beberapa problem yang dihadapi, diantaranya adalah problem akad yang masih diperdebatkan (Hakim, 2016) dan juga problem sumberdaya manusia dalam perbankan yang perlu untuk segera diselesaikan (Noviyanti, 2018). Adanya keharusan perbankan syariah memiliki asas syariah yang telah tertuang dalam peraturan, tidak serta merta bank syariah terhindar dari aktivitas transaksi dengan perbankan syariah yang pada akhirnya menimbulkan kegiatan yang tidak berdasarkan prinsip syariah atau disebut sebagai dana non halal. Terjadinya kegiatan transaksi antara perbankan syariah dengan konvensional merupakan hal yang tidak dapat dihindari dikarenakan lembaga keuangan konvensional masih mendominasi seluruh transaksi di setiap negara (Maulidha, 2014; Muwazir et al, 2016).

Adanya persoalan tersebut, maka mayoritas ulama berpendapat bahwa dana non halal hanya dapat disalurkan untuk fasilitas umum seperti pembangunan jalan raya dan MCK. Sedangkan sebagian ulama, seperti Yusuf al-Qardhawi dan alQurrah Dagi berpendapat, bahwa dana non-halal boleh disalurkan untuk seluruh kebutuhan sosial (aujuh al-khair), baik fasilitas umum (al-mashalih al-ammah), ataupun selain fasilitas umum, seperti hajat konsumtif faqir, miskin, termasuk program-program pemberdayaan masyarakat.

Adanya dana non halal tersebut, maka muncul peraturan mengenai penyajian dana non halal dalam Pernyataan Standar Akuntansi (PSAK)101 mengenai penyajian laporan keuangan syariah. PSAK 101 menyebutkan bahwa pendapatan non halal dari perbankan syariah harus disajikan dalam laporan keuangan sebagai bagain dari laporan sumber dan penggunaan dana kebajikan. Selain itu, disebutkan juga bahwa perbankan syariah juga harus menjelaskan alasan terjadinya dan penggunaan pendapatan non halal tersebut. Tidak diungkapkannya laporan sumber dan penggunaan dana kebijakan dapat menjadi ukuran tingkat kepatuhan syariah (Suprayogi, 2013) serta komitmen terhadap tanggungjawab sosial (Haniffa dan Hudaib, 2007). Pengungkapan dana kebijakan 
juga dapat dimaknai sebagai suatu sikap dari perbankan Syariah untuk menjaga dan memelihara kepercayaan stakeholders (Ali, 2012; Meutia, 2010; Harkaneri dan Reflisa, 2018).

Penelitian mengenai pengungkapan dana kebajikan pernah dilakukan oleh Harahap (2003) yang menunjukkan hasil bahwa Bank Muamalat Indonesia (BMI) belum memenuhi disclosure secara rinci mengenai PSAK 101, dana kebajikan dapat digunakan untuk dana kebajikan produktif, sumbangan, dan penggunaan lainnya untuk kepentingan umum. Hal tersebut juga senada dengan hasil penelitian yang dilakukan oleh Balangger et al. (2017) pada Bank BRI Syariah Cabang Manado, dimana masih terdapat ketidaksesuai dalam penyaluran zakat dan dana kebajikan.

Roziq dan Yanti (2011) yang melakukan penelitian mengenai penyajian dan pengungkapan dana non halal pada Lembaga Amil Zakat menunjukkan hasil bawah Lembaga Amil Zakat masih belum sesuai dengan ketentuan perlakuan akuntansi dana non halal yang meliputi pengakuan, pengukuran, penyajian dan pengungkapan. Sementara itu, Hisamudin dan Sholikha (2014) yang melakukan penelitian pada Badan Amil Zakat (BAZNAS) dan Pos Keadilan Peduli Umat (PKPU) menemukan hasil bahwa BAZNAS dan PKPU telah melakukan pengungkapan penggunaan dana non halal tersebut.

Penelitian mengenai pendapatan non halal di perbankan Syariah Indonesia menunjukkan bahwa pendapatan non halal telah disajikan sesuai dengan PSAK 101 tentang pendapatan non halal oleh (Lenap, 2019). Solehodin et al. (2014) dan Zubaidah (2018) yang melakukan penelitian terhadap Lembaga keuangan Syariah menunjukkan hasil bahwa Lembaga keuangan Syariah masih menggunakan pendapatan non halal sebagai sumber dan penggunaan dalam qardhul hasan. Adiono dan Sholihin (2014) dan Anam (2017) mengungkapkan bahwa perbankan syariah masih belum memiliki komitmen untuk mengungkapan pendapatan non halal mererka dari tahun ke tahun dalam laporan tahunan. Hasil penelitian di luar negeri mengenai perbankan Syariah pernah dilakukan oleh Maali et al (2006) yang menunjukkan hasil bahwa hanya 12 dari 29 sampel perbankan yang mengungkapan secara jelas jumlah pendapatan non halal. Al Haneef et al. (2017) melakukan penelitian di perbankan Syariah di Malaysia menunjukkan hasil bahwa perbankan Syariah Malaysia menyalurkan pendapatan non halal melalui badan amal.

Berdasarkan penjelasan diatas, dapat disimpulkan bahwa perbankan diwajibkan mengungkapan sumber dan penggunaan pendapatan non halal tersebut sebagai bagian dari laporan keuangan. Penggunaan dana pendapatan non halal yang diperoleh perbankan syariah juga harus digunakan sesuai dengan kaidah-kaidah syariah. Selain itu, sampai dengan saat ini penelitian mengenai pendapatan non halal perbankan Syariah masih terbatas pada pengungkapan pendapatan non halal. Oleh karena itu, penelitian ini dilakukan untuk menganalisis lebih dalam yaitu bukan hanya dari penyajian dan pengungkapan saja akan tetapi juga menganalisis 
kesesuaian antara sumber dan penggunaan pendapatan non halal perbankan Syariah dengan kaidah kaidah-kaidah syariah yang ada.

\section{Tinjauan Pustaka}

\subsection{Teori Legitimasi}

Teori legitimasi menyatakan bahwa perusahaan akan terus menerus meyakinkan bahwa kegiatan atau aktivitas yang dilakukannya telah sesuai dengan batasan dan norma-norma yang berlaku dimasyakarat (Suchman, 1995). Jika terjadi ketidaksesuaian antara nilai perusahaan dengan nilai atau norma masyarakat, maka perusahaan akan kehilangan legitimasinya yang pada akhirnya akan mengancam keberlangsungan hidup perusahaan (Lindblom, 1994).

Implikasi teori legitimasi dalam perbankan syariah adalah keberadaan dewan direksi dan Dewan Pengawas Syariah (DPS) (Muchlis dan Utomo, 2018). DPS memiliki tugas dan wewenang yang diatur dalam keputusan dewan syariah nasional No. 3 Tahun 2000 tentang Petunjuk Pelaksanaan Penetapan Anggota Dewan Pengawas Syariah Pada Lembaga Keuangan Syariah. Tugas DPS adalah mendiskusikan masalah dan transaksi usaha mengenai kesesuaian dengan prinsip syariah. Sedangkan wewenang DPS syariah adalah memberikan pedoman syariah kepada bank dalam rangka menjalankan aktivitas syariah di perbankan syariah serta memberikan perbaikan jika terdapat aktivitas yang tidak sesuai dengan prinsip syariah (Misbach, 2005).

\subsection{Penerimaan Non Halal Perbankan Syariah}

Dalam PSAK 101 mengenai penyajian laporan keuangan syariah menyebutkan definisi penerimaan non halal sebagai semua penerimaan dari kegiatan yang tidak sesuai dengan prinsip syariah antara lain penerimaan jasa giro atau bunga yang berasal dari bank umum konvensional. Penerimaan non halal pada umumnya terjadi dalam kondisi darurat atau kondisi yang tidak diinginkan oleh entitas syariah karena secara prinsip dilarang. Dewan Syariah MUI juga memberikan pengertian yang sama mengenai penerimaan atau pendapatan non hala sebagai setiap pendapatan yang bersumber dari usaha yang tidak halal (al-kasbu alghairi al-mayru'). Lebih lanjut lagi, penerimaan non halal dalam PSAK 101 disebutkan sebagai salah satu sumber penerimaan dari dana kebijakan.

PSAK 101 mewajibkan seluruh entitas untuk menyajikan laporan penggunaan dana kebajikan sebagai komponen utama laporan keuangan yang menunjukkan: a) sumber dana kebajikan; b) penggunaan dana kebajikan; c) kenaikan atau penurunan sumber dana kebajikaan; d) saldo awal dana penggunaan kebajikan; dan d) saldo akhir dana penggunaan kebajikan. Oleh karena itu, pendapatan non halal sebagi bagian dari sumber dana kebajikan perlu diungkapan dalam laporan keuangan perbankan syariah. Pengungkapan tersebut dapat berupa alasan terjadinya serta penggunaan atas penerimaan non halal. 
Penerimaan non halal menurut Sahroni (2014) dapat berupa: a) bunga atas transaksi pinjaman; b) Pendapatan dari usaha yang aktifitas pinjaman berbunga lebih dominan; c) Pendapatan dari usaha perjudian, minuman keras, barang merusak moral dan mudharat. Fatwa Dewan Syariah Nasional (DSN) MUI juga menjelaskan bahwa jenis kegiatan usaha yang bertentangan dengan prinsip syariah antara lain: pertama, usaha Lembaga keuangan konvensional, seperti usaha perbankan konvensional dan asuransi konvensional. Kedua, melakukan investasi pada emiten (perusahaan) yang pada saat transaksi, porsi (nisbah) utang perusahaan kepada lembaga keuangan ribawi lebih dominan dari pada modalnya. Ketiga, perjudian dan permainan yang tergolong judi atau perdagangan yang terlarang. Keempat, produsen, distiributor, serta pedagang makanan dan minuman yang haram. Kelima, produsen, distributor dan atau penyedia barang-barang ataupun jasa yang merusak moral atau bersifat mudarat.

Berkaitan dengan penerimaan non halal perbankan syariah, para ulama sepakat bahwa dana non halal tidak dimanfaatkan oleh pemiliknya, akan tetapi harus disedekahkan kepada pihak lain. Bentuk penyerahan kepada pihak lain berbeda pendapat diantara para ulama, mayoritas ulama berpendapat, bahwa dana nonhalal hanya boleh disalurkan untuk fasilitas umum (al-mashlalih al-ammah), seperti pembangunan jalan raya, MCK. Sedangkan sebagian ulama, seperti alQardhawi dan al-Qurrah Dagi berpendapat, bahwa dana non-halal boleh disalurkan untuk seluruh kebutuhan sosial (aujuh al-khair), baik fasilitas umum (al-mashalih al-ammah), ataupun selain fasilitas umum, seperti hajat konsumtif faqir, miskin, termasuk program-program pemberdayaan masyarakat (Sahroni, 2016).

\subsection{Pengembangan Hipotesis}

Berdasarkan Undang-undang No. 21 Tahun 2008 Tentang Perbankan Syariah, Perbankan syariah mencakup atas Bank Umum Syariah (BUS), Unit Usaha Syariah (UUS), dan Bank Pembiayaan Rakyat Syariah (BPRS). Perbedaan ketiga jenis bank tersebut adalah terletak pada kegiatannya. Bank Umum Syariah dan Unit Usaha Syariah Bank Syariah yang dalam kegiatannya memberikan jasa dalam lalu lintas pembayaran. UUS merupakan unit kerja dari kantor pusat Bank Umum Konvensional yang berfungsi sebagai kantor induk dari kantor atau unit yang melaksanakan kegiatan usaha berdasarkan Prinsip Syariah, atau unit kerja di kantor cabang dari suatu Bank yang berkedudukan di luar negeri yang melaksanakan kegiatan usaha secara konvensional yang berfungsi sebagai kantor induk dari kantor cabang pembantu syariah dan/atau unit syariah.Sedangkan untuk BPRS kegiatannya adalah kegiatan keuangan syariah selain penyediaan jasa lalu lintas pembayaran. Perbedaan ketiga aktivitas jenis perbankan tersebut menyebabkan perbedaan tingkat kompeksitas baik dari segi sumber maupun pengelolaan dana atau jasa keuangan syariah. Adanya perbedaan tingkat kompleksitas tersebut mendorong peneliti untuk melakukan analisis mengenai 
sumber dan penggunaan dana non halal yang diperoleh BUS dan UUS. Oleh karena itu, kerangka pikir dalam hipotesis dalam penelitian ini adalah sebagai berikut: Ho = Tidak terdapat perbedaan pengungkapan sumber dan penggunaan dana non halal antara Bank Umum Syariah dan Unit Usaha Syariah. Ha = Terdapat perbedaan pengungkapan sumber dan penggunaan dana non halal antara Bank Umum Syariah dan Unit Usaha Syariah.

\section{Metode Penelitian}

Penelitian ini adalah kuantitatif menggunakan data sekunder yang telah disediakan dan dipublikasikan oleh pihak lain berupa laporan tahunan maupun laporan keuangan perbankan syariah. Penelitian ini menggunakan pengujian uji t untuk menguji apakah terdapat perbedaan pengungkapan, sumber dan penggunaan dana non halal antara BUS dengan UUS.

Populasi dalam penelitian ini adalah perbankan syariah di Seluruh Indonesia dengan jumlah perbankan per tahun adalah 34 perbankan syariah dengan rincian 13 BUS dan 21 UUS. Penelitian ini menggunakan teknik purposive sampling. Sampel yang digunakan dalam penelitian ini didasarkan kelengkapan data yang diperoleh untuk digunakan dalam pengujian. Data yang digunakan dalam penelitian ini merupakan jenis data sekunder yang berupa laporan tahunan perbankan syariah tahun 2014-2017. Penelitian ini bersifat unbalanced panel dikarenakan adanya sifat times series dan cross section dari data yang dikumpulkan. Laporan perbankan syariah diperoleh dari website masing-masing perbankan. Kelengkapan data dalam laporan perbankan yang dapat diperoleh selama tahun 2015-2017 adalah sebanyak 102 perbankan. Tabel 3.1 menunjukkan bahwa terdapat laporan tata kelola perbankan yang diperoleh sebanyak sampel sebanyak 102 perusahan selama 3 tahun yaitu dengan rincian masing-masing tiap tahun sebanyak 34 laporan. Sehingga sampel akhir dalam penelitian ini adalah 102 perbankan.

Tabel 1.2

Kriteria Pengambilan Sampel

\begin{tabular}{clcc}
\hline No & \multicolumn{1}{c}{ Kriteria } & $\begin{array}{c}\text { Tidak } \\
\text { Memenuhi } \\
\text { Syarat }\end{array}$ & $\begin{array}{c}\text { Memenuhi } \\
\text { Syarat }\end{array}$ \\
\hline 1 & $\begin{array}{l}\text { Laporan Tahunan } \\
\text { Perbankan syariah } \\
\text { yang dipublikasikan } \\
\text { di website } \\
\text { Tidak } \\
\text { mempublikasikan } \\
\text { laporan tahunan } \\
\text { Terdapat data outlier }\end{array}$ & 0 & 102 \\
\hline $3 \quad$ Total Sampel (2015-2017) & 0 & 0 \\
\hline Sumpras
\end{tabular}

Sumber: Data diolah, 2018

Falah: Jurnal Ekonomi Syariah 


\section{Analisis dan Pembahasan}

Berdasarkan penelitian yang telah dilakukan, berdasarkan data pada tabel 1.3, menunjukkan bahwa jumlah terbesar nilai dari dana non halal adalah sekitar 5,6 miliar yang berasal dari bank muamalat indonesia. Sedangkan nilai terendah dari dana non halal adalah nol rupiah yang berarti terdapat perbankan syariah yang tidak memiliki penerimaan dana non halal. Jika dilihat berdasarkan klasifikasi jenis perbankan yang ada pada penjelasan tabel 1.3, maka dapat diketahui bahwa jenis perbankan yang masuk kedalam Unit Usaha Syariah (UUS) selama tahun 2015-2017 adalah sebanyak 63 perbankan syariah dengan jumlah masing-masing tiap tahun adalah sebanyak 21 perbankan syariah. Sedangkan jumlah Bank Umum Syariah (BUS) selama tahun 2015-2017 adalah sebanyak 39 perbankan syariah dengan jumlah masing-masing tiap tahun adalah sebanyak 13 perbankan syariah.

Tabel 1.3

\section{Analisis Deskriptif Dana Non-Halal di Bank Unit Usaha Syariah dan Bank Umum Syariah}

\begin{tabular}{|c|c|c|c|c|}
\hline Keterangan & $\mathbf{N}$ & Minimum & Maximum & Mean \\
\hline Dana Non Halal & 102 & 0,00 & 5.689 .576 .976 & $152.043 .791,2$ \\
\hline $\begin{array}{l}\text { Dana Non Halal- Unit } \\
\text { Usaha Syariah }\end{array}$ & 63 & 0,00 & 245.000 .000 & $10.045 .958,00$ \\
\hline $\begin{array}{l}\text { Danan Non Halal- Bank } \\
\text { Umum Syariah }\end{array}$ & 39 & 0,00 & 5.689 .576 .976 & 383.709 .393 \\
\hline Jenis_Bank & 102 & 0,00 & 1,00 & 0,3824 \\
\hline Valid N (listwise) & 102 & & & \\
\hline
\end{tabular}

Pada tabel di atas juga dapat dilihat juga nilai minimum dana non halal yang dimiliki oleh sampel unit usaha syariah adalah Rp. 0 dan nilai maksimum adalah sebesar Rp. 245.000.000 serta nilai rata-rata dana non halal yang dimiliki unit usaha syariah adalah Rp. 10.045.958. Dana non halal yang dimiliki oleh BUS jika dilihat berdasarkan nilai minimul adalah sebesar Rp. 0 dan nilai maksimum sebesar Rp. 5,6 miliar serta nilai rata-rata adalah sebesar Rp. 383 juta. Berdasarkan penjelasan tersebut dapat diambil kesimpulan bahwa unit usaha syariah memiliki jumlah dana non halal lebih sedikit daripada bank umum syariah.

Berdasarkan analisis uji $\mathrm{T}$, hasil pengujian menunjukkan bahwa berdasarkan output table 4.2 diperoleh nilai sig. (2-tailed) sebesar 0,003 $<0,05$, maka sesuai dengan pengambilan keputusan dalam uji Independent sample t-tes, maka dapat disimpulkan Ho ditolak dan Ha diterima, yang artinya terdapat perbedaaan antara rata-rata dana non halal UUS dengan BUS. Selain dengan menggunakan 
analisis uji $\mathrm{T}$, penelitian ini juga menggunakan analisis deskriptif dalam mengelompokkan sumber dan penggunaan dana non halal.

Tabel 1.4

Hasil Uji T

\begin{tabular}{ccccccc}
\hline & & \multicolumn{2}{c}{$\begin{array}{c}\text { Levene's Test for } \\
\text { Equality of Variances }\end{array}$} & \multicolumn{3}{c}{$\begin{array}{c}\text { t-test for Equality of } \\
\text { Means }\end{array}$} \\
\cline { 2 - 7 } Keterangan & $\mathbf{F}$ & Sig. & T & df & Sig. \\
\hline $\begin{array}{c}\text { Dana } \\
\text { Non }\end{array}$ & $\begin{array}{c}\text { Equal variances } \\
\text { assumed } \\
\text { Equal variances } \\
\text { Halal }\end{array}$ & 14,409 & 0,000 & $-3,032$ & 100 & 0,003 \\
\hline Sumber: Data diolah, 2019 & & & $-2,386$ & 38,302 & 0,022 \\
\hline
\end{tabular}

Tabel 1.5

Sumber dan Penggunaan Dana Non Halal Perbankan Syariah

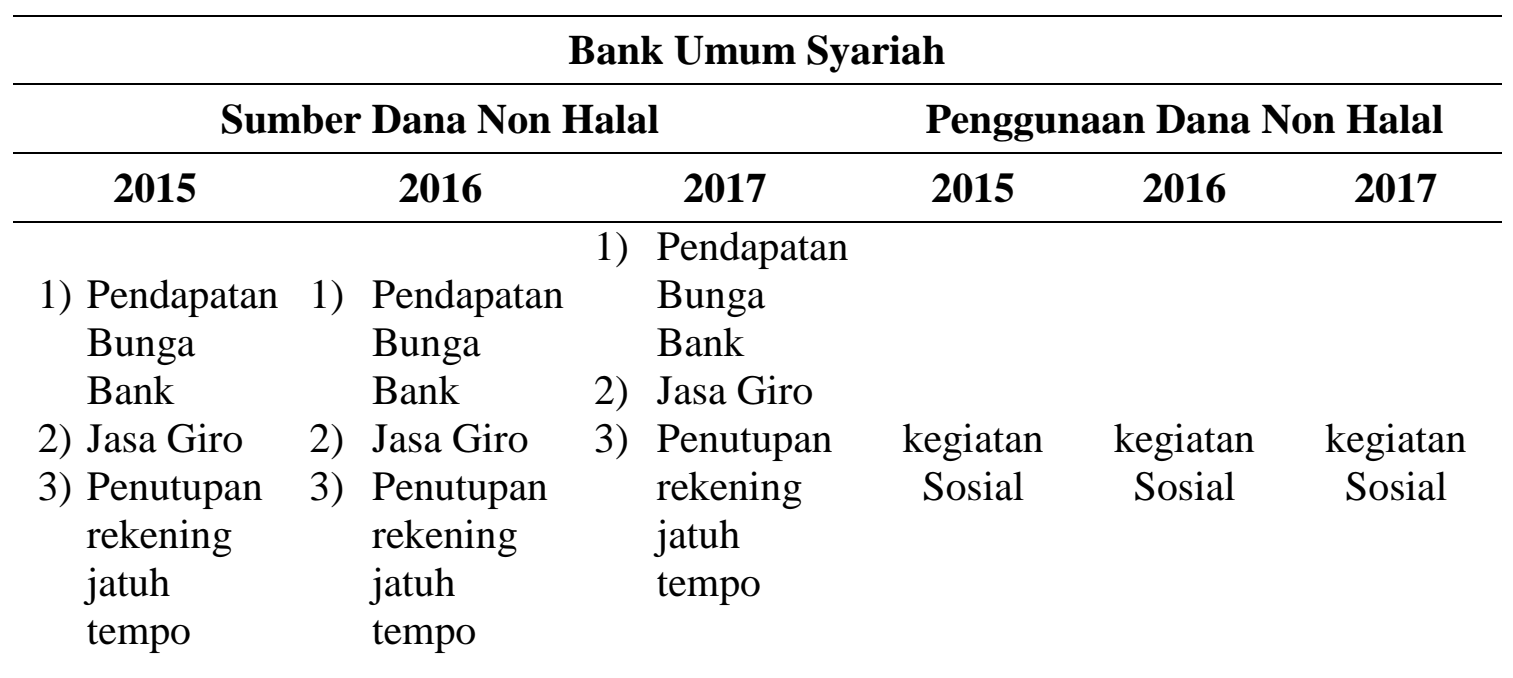

Unit Usaha Syariah

\begin{tabular}{cccccc}
\hline \multicolumn{2}{c}{ Sumber Dana Non Halal } & \multicolumn{3}{c}{ Penggunaan Dana Non Halal } \\
\hline $\mathbf{2 0 1 5}$ & $\mathbf{2 0 1 6}$ & $\mathbf{2 0 1 7}$ & $\mathbf{2 0 1 5}$ & $\mathbf{2 0 1 6}$ & $\mathbf{2 0 1 7}$ \\
\hline $\begin{array}{c}\text { Pendapatan } \\
\text { Bunga }\end{array}$ & $\begin{array}{c}\text { Pendapatan } \\
\text { Bunga }\end{array}$ & $\begin{array}{c}\text { Pendapatan } \\
\text { Bunga }\end{array}$ & belum & belum & belum \\
Sumber: Data diolah, 2019 & & & & &
\end{tabular}

Berdasarkan tabel di atas, dapat dilihat bahwa sumber dana non halal Bank Umum Syariah selama tahun 2015-2017 dapat diklasifikasikan menjadi tiga sumber yaitu: 1) Pendapatan Bunga Bank; 2) Jasa Giro; 3) penutupan rekening jatuh tempo dan pada Unit Usaha Syariah sumber danan non halal didominasi oleh pendapatan bunga. Jika dilihat dari segi penggunaan dana non halal, Bank

Falah: Jurnal Ekonomi Syariah 
umum syariah mendistribusikan dana non halal kepada penggunaan kegiatan sosial sedangkan untuk unit usaha syariah selama tahun 2015-2017 belum mengungkapkan penggunaan dana non halal serta adanya pengungkapan informasi mengenai belum ada penyaluran dana non halal tersebut.

Selain itu, jika berdasarkan tingkat pengungkapan informasi dalam laporan keuangan yang tersedia pada tabel 1.6 dapat dijelaskan bahwa tingkat pengungkapan informasi sumber dana non halal pada bank umum syariah dan unit usaha syariah adalah sebanyak $100 \%$ yang berarti seluruh perbankan syariah dari tahun 2015-2017 sudah mengungkapkan informasi sumber dana non halal. Hasil tersebut telah konsisten dengan penelitian Lenap (2019) dan Haneef et al. (2017). Dilain sisi, tingkat pengungkapan informasi penggunaan dana non halal cenderung rendah. Hal tersebut dapat dilihat dari pengungkapan informasi penggunaan dana yaitu sebanyak $100 \%$ perbankan syariah yang hanya ada ditahun 2015 dan 2016 dan hanya terdapat pada unit usaha syariah.

Tabel 1.6

Pengungkapan Informasi Pendapatan Non Halal dalam Laporan Keuangan Perbankan

\begin{tabular}{lcccccc}
\hline & \multicolumn{5}{c}{ Pengungkapan Informasi } \\
\cline { 2 - 7 } \multicolumn{1}{c}{ Jenis Bank } & \multicolumn{3}{c}{ Sumber Dana Non Halal } & \multicolumn{3}{c}{$\begin{array}{c}\text { Penggunaan Dana Non } \\
\text { Halal }\end{array}$} \\
\cline { 2 - 7 } & $\mathbf{2 0 1 5}$ & $\mathbf{2 0 1 6}$ & $\mathbf{2 0 1 7}$ & $\mathbf{2 0 1 5}$ & $\mathbf{2 0 1 6}$ & $\mathbf{2 0 1 7}$ \\
\hline $\begin{array}{l}\text { Bank Umum } \\
\text { Syariah }\end{array}$ & $100 \%$ & $100 \%$ & $100 \%$ & $58 \%$ & $67 \%$ & $58 \%$ \\
$\begin{array}{l}\text { Unit Usaha } \\
\text { Syariah }\end{array}$ & $100 \%$ & $100 \%$ & $100 \%$ & $100 \%$ & $100 \%$ & $67 \%$ \\
\hline Sumber: Data diolah, 2019 & & & &
\end{tabular}

5. Kesimpulan

Berdasarkan hasil analisis dan pembahasan dapat diambil kesimpulan sebagai berikut: pertama, terdapat perbedaan rata-rata antara dana non halal yang diperoleh Bank Umum Syariah dengan Unit Usaha syariah. Perbedaan tersebut juga dapat dilihat dari adanya dominasi penerimaan dana non halal yang lebih banyak di Bank Umum Syariah. Dimana, sumber dana non halal di Bank Umum Syariah dan Unit Usaha Syariah didominasi oleh pendapatan bunga bank dan jasa giro. Sedangkan penggunaan dana non halal didominasi oleh kegiatan sosial. Penggunaan dana non halal tersebut telah sesuai dengan pendapat Sahroni (2016) yang menyatakan bahwa para ulama sepakat bahwa dana non halal tidak dimanfaatkan oleh pemiliknya, akan tetapi harus disedekahkan kepada pihak lain. Sementara itu, pengungkapan informasi sumber dana non halal sudah baik sekali dimana $100 \%$ seluruh perbankan telah mengungkap informasi sumber dana non halal. Sedangkan pengungkapan informasi penggunaan dana non halal sudah 
cukup baik dimana hal tersebut dapat dilihat dari diatas $50 \%$ jumlah perbankan sudah mengungkapan informasi penggunaan dana non halal dari tahun 2015-2017.

Berdasarkan hasil analisis dan pembahasan berikut Bank Umum Syariah yang memiliki dana non halal lebih banyak daripada Unit Usaha Syariah perlu mengurangi aktivitas penerimaan dana non halal yang diperoleh. Pengurangi penerimaan dana non halal menjadi penting karena semakin besar dana non halal yang dimiliki oleh perbankan syariah maka semakin besar potensi penurunan kepercayaan nasabah terhadap perbankan syariah (Muchlis dan Utomo, 2018). Selain itu, perbankan syariah yang memiliki pendapatan non halal yang rendah cenderung diminati oleh investor yang pada akhirnya juga akan berdampak pada meningkatnya nilai perusahaan (Adlan dan Mawardi, 2018). Selain itu, bank syariah di Indonesia dipandang perlu untuk melakukan peningkatan pengungkapan informasi yang lebih baik dan detail mengenai sumber dan penggunaan dana non halal.

Implikasi dari penelitian ini adalah, perlunya perhatian yang lebih dari setiap Dewan Pengawas Syariah (DPS) yang merupakan merupakan unsur utama sebagai kelangsungan dan keberadaan usaha bank Syariah (Ilhami, 2009; Minarni, 2013) untuk mengawasi kepatuhan prinsip-prinsip Syariah termasuk pendapatan non halal perbankan (Yusof et al, 2019).

\section{Daftar Pustaka}

Adlan dan Mawardi. 2018. Analisis Pengaruh Utang Berbasis Bunga dan Pendapatan Non-Halal Terhadap Nilai Perusahaan Emiten Saham Syariah. Jurnal Ekonomi dan Bisnis Islam, 4(2),103-128.

Adiono, C. L., \& Sholihin, M. 2014. Analisis pengungkapan tata kelola bank syariah di Indonesia. Jurnal Keuangan dan Perbankan, 18(2), 268-377.

Al Haneef, S. S., Kamaruddin, Z., \& Mahmud, M. W. 2017. Purification of NonHalal Income in Malaysian Islamic Banks: An Overview (Penyucian Pendapatan Tidak-Halal Di Bank-Bank Islam Malaysia: Satu Tinjauan). Journal of Islam in Asia, 14(2), 305-326.

Ali, I. M. A. 2012. Memaknai Disclosure Laporan Sumber dan Penggunaan Dana Kebajikan (Qardhul Hasan) Bank Syariah. Jurnal Akuntansi Multiparadigma, 3(2), 187-209.

Anam, M. K. (2017). Penerapan Psak 101 Pada Laporan Dana Zakat Dan Dana Kebajikan. Misykat al-Anwar Jurnal Kajian Islam dan Masyarakat, 28(2), 114.

Balangger RF., H.Karamoy dan H.Gamaliel. 2017. Evaluasi Pengungkapan Dana Zakat dan Dana Kebajikan pada Laporan Keuangan Bank BRI Syariah Cabang Manado. Jurnal Ekonomi dan Manajemen Bisnis, 5(2) 19561964.

Ghozali, Mohammad. Azmi, Muhammad Ulul. \& Nugroho, Wahyu. 2019. Perkembangan Bank Syariah Di Asia Tenggara: Sebuah Kajian Historis. Falah: Jurnal Ekonomi Syariah, (4)1, 44-55 
Hakim, Rahmad. 2016. Pembangunan Ekonomi Islam Pada Perbankan Syari'ah: Telaah Beberapa Problem Dalam Transaksi Mudarabah Kontemporer. Islamic Economics Journal 1(1), 61-83

Harkaneri dan Reflisa. 2018. Pendapatan Non Halal Sebagai Sumber Dan Penggunaan Qardhul Hasan Dalam Perspektif Islam. Jurnal Rumpun Ekonomi Syariah, 1(2), 102-110.

Haniffa, R. \& M. Hudaib 2007. Exploring the Ethical Identity of Islamic Banks via Communication in Annual Reports. Journal of Business Ethics, 76: 97116.

Harahap, S. 2003. The disclosure of Islamic values-annual report. The analysis of Bank Muamalat Indonesia's annual report. IQTISAD Journal of Islamic Economics, 3(1), 35-45.

Hisamuddin dan Sholikha, I. H. 2016. Persepsi, Penyajian dan Pengungkapan Dana Non Halal Pada BAZNAS dan PKPU Kabupaten Lumajang. ZISWAF: Jurnal Zakat dan Wakaf, 1(1), 1-36.

Ilhami, Haniah. 2009. Pertanggung jawaban Dewan Pengurus Syariah Sebagai Otoritas Pengawas Kepatuhan Syariah Bagi Bank Syariah. Jurnal Mimbar Hukum. 21(3), 409-628.

Lenap, I.P, 2019. Pengungkapan Pendapatan Non Halal: PSAK 109 VS Praktik. Jurnal Aplikasi Akuntansi. 3(2), 94-116.

Lindblom, C.K., 1994. The implications of organizational legitimacy for corporate socia performance and disclosure. Working Paper for the American Accounting Association Public Interest Section, USA

Maali, B., Casson, P., \& Napier, C. 2006. Social Reporting by Islamic banks. Abacus, 42(2), 266-289.

Maulidha. 2014. Kerangka Pengungkapan Transaksi Non Halal di Bank Syariah. Simposun Nasional Akuntansi Syariah 1.Jakarta

Meutia, Inten. 2010. Shariah Enterprise Theory sebagai Dasar Pengungkapan Tanggung Jawab Sosial untuk Bank Syariah. Disertasi Tidak Dipublikasikan. Malang: Doktor Ilmu Akuntansi Program Pascasarjana Universitas Brawijaya.

Minarni. 2013. Konsep Pengawasan, Kerangka Audit Syariah, Dan Tata Kelola Lembaga Keuangan Syariah. Jurnal Ekonomi Islam, 5(1), 29-40.

Misbach, I. 2015. Kedudukan Dan Fungsi Dewan Pengawas Syariah Dalam Mengawasi Transaksi Lembaga Keuangan Syariah Di Indonesia. Jurnal Minds: Manajemen Ide dan Inspirasi, 2(1), 79-93.

Muchlis, S., \& Utomo, H. S. 2018. Kajian Pendapatan Non Halal Dan Dampak Penggunaannya Terhadap Reputasi Dan Kepercayaan Nasabah Perbankan Syariah. Jurnal Riset Akuntansi dan Komputerisasi Akuntansi, 9(1), 75-101.

Muwazir, M.R, M., Rusnah, M., dan Kamaruzaman, N. 2006. Corporate social responsibility disclosure: a Tawhidic approach. Jurnal Syariah, 14(1), 125142

Noviyanti, Ririn. 2018. Bank Syariah: Antara Konsepsi dan Implementasi, Iqtishodia: Jurnal Ekonomi Syariah, Vol 3 No 1, 21-38

Roziq, Ahmad dan W Yanti. 2011. Pengakuan, Pengukuran, Penyajian dan Pengungkapan Dana Non-Halal pada Laporan Keuangan Lembaga Amil Zakat. Jurnal Akuntansi Universitas Jember, 11(2), 20-47. 
Sahroni. 2014. Pemasukan dana non halal di Lembaga keuangan Syariah (LKS) dalam perspektif Syariah. Muzakarah Cendekiawan Syariah Nusantara ke-8.

Sahroni. 2016. Apa Maksud Dana Non Halal, diakses tanggal 30 Maret 2019. https://haji.okezone.com/read/2016/06/07/428/1408132/apa-maksud-dananon-halal (online).

Solehodin, Robiatul Uliyah dan Rahmat Zuhdi. 2014. Ahsankah Pendapatan Non Halal Pada Qardhul Hasan?. Simposun Nasional Akuntansi Syariah 1.Jakarta

Suchman, M. C. 1995. Managing legitimacy: Strategic and institutional approaches. Academy of management review, 20(3), 571-610.

Suprayogi, N. 2013. Menyingkap Shari'a Compliance Bank Syariah Dari Laporan Keuangan. Majalah Sharing Edisi Januari.

Undang-undang No. 21 Tahun 2008 Tentang Perbankan Syariah. Jakarta: Bank Indonesia.

Yusof, M. F. M., Romli, N., Khalid, M. M., Bhari, A., \& Yaakob, M. A. Z. 2019. Fungsi Dan Tanggungjawab Kakitangan Bukan Syariah Dalam Pengurusan Risiko Syariah: Kajian Terhadap Praktis Syarikat Takaful di Malaysia (Functions And Responsibilities of Non-Shariah Staff In Shariah Risk Management: A Study of Malaysian Takaful Companies). UMRANInternational Journal of Islamic and Civilizational Studies, 6(2), 51-66.

Zubaidah. 2018. Analisis Dana Non Halal Dalam Pembiayaan Qordhul Hasan Perspektif Maqashid Al-Syari'ah. Skripsi tidak Dipublikasikan. Lampung: Fakultas Syariah UIN Raden Intan Lampung. 